\title{
Factors behind Classroom Participation of Secondary School Students (A Gender Based Analysis)
}

\author{
Fakhra Aziz, Uzma Quraishi", Asma Shahid Kazi \\ Department of Education, Faculty of Humanities \& Social Sciences, Lahore College for Women University, Lahore, Pakistan
}

Copyright $(2018$ by authors, all rights reserved. Authors agree that this article remains permanently open access under the terms of the Creative Commons Attribution License 4.0 International License

\begin{abstract}
It is evidence based conclusion that students' classroom participation makes them more motivated, supports their learning, improves their communication and promotes higher order thinking skills. The current study was an intention to investigate the current level of secondary school students' classroom participation and to identify the underlying factors that contribute to it. The study was conducted on $9^{\text {th }}$ and $10^{\text {th }}$ grade students, randomly selected from 19 boys' and 21 girls' government high schools in Lahore city. Sampling process consisted of two stages. In the first stage, $10 \%$ sample size was calculated which led to random selection of 4 schools, two from each cohort. At second stage, 500 students were purposively selected from 1689 students, 250 from each cohort. A self-report questionnaire (FBCPS) was used to collect data. Response rate was 70\%. Simple descriptive and inferential statistics were used to analyze the data. The study concluded that students exhibit significant level of classroom participation. Further boys participated more in the class as compare to girls, while internal and external factors behind their classroom participation were same, although the extent to which they influence was different. Girls were influenced by motivation in their classroom participation as compared to boys. Boys' participated more due to high self-esteem. Teachers, parents and peers and curriculum are important external factors which supported boys classroom participation more than girls who in turn more influenced by classroom environment.
\end{abstract}

Keywords Classroom Participation, Performance, Participation Factors

\section{Introduction}

The term classroom participation is poorly defined and is hard to measure. Literature considers it as an aspect of engagement as it is frequently used to describe students inclination to participate in daily class activities such as regularity, timely submission of homework and following teachers' instructions in class. Petress [1] and Weaver and Qi [2] provide strong evidence about significance of classroom participation. According to Cohen [3] students can be brought actively into the teaching learning process and can facilitate teaching by their participation in the classroom.

Classroom discussions are an important aspect of participation, which are "spontaneous, not easily created" as elucidated by Howard [4]. He elaborates that elicited discussions may yield blank faces, but at times a healthy discussion can also break out without any conscious prompt. Facilitating effective class participation and discussion requires "forethought, planning and structure". In their seminal work Chickering and Gamson [5] emphasized the importance of active learning, which has been validated by research in the past 30 years by many such as Pascarella and Terenzini [6]. Kuh and Umbach. [7] link student engagement as a crucial factor which leads to academic success.

Classroom participation involves a variety of activities and has different forms, like students' simple questions and explanations [26]. Duration of participation is also varying for individual to individual, it can take a few moments or a long time [27]. Discussion, dialogue, presentations are most common and effective ways of classroom participation at secondary level. Wade [28] opined that ideal class discussion require participation, interest, learning of all the students and absorbing others' explanations and information. Distinctive social and cultural tenets, contextual including family and circumstantial experiences, and previous information and assumptions are brought to discussion by students. Anderson [29] and Hatano [30] opine that classroom collaborations lead to integration of students' thinking and behaving in a productive way. This enhances their knowledge, abilities and dispositions required for independent problem solving. Reznitskaya [31] said that the skill and character to take more than one perspective emerge from participating in discussions with those who hold different perceptions. Fawzia [32] found that "pedagogical factors like the course, topic, lecturer and 
teaching style could influence students' participation".

Small group activities are another type of participation where there is collaboration amongst the participants, which is then reported in a plenary discussion [15]. Some instructors also tend to include email discussions, blogs, journals and online activity as a form of collaborative participation.

Despite all emphasis on student participation, researchers such as Reda [8] iterate that "speaking does not automatically result in learning." While some students may learn more by verbal interaction, there might still be some who silently absorb and process the material being taught. Therefore class participation may assume different types of engagement activities. Several types of classroom participation have been elucidated in research [9-2]. Two main types of participation are questions students ask of their teachers, and questions teachers direct to students. Besides these there are passive participants, who largely remain silent and make their presence felt by some gesture, or merely by being conspicuously seated in the class. The para participants interact with the teacher before or after class, and remain passive during class hours [2]. The negative participants are vocal, active, but veer the discussion into another direction and "monopolize the discussion" [10-11] as cited in Loftin and Hartin [12].

Another important category of student involvement is compulsory or forced participation, where the teacher picks a specific student to respond. This has also been defined as "cold calling" by Dallimore, Hertenstein, and Platt [14]. In such scenarios, students like being forewarned that any one of them might be chosen randomly to respond. Non-participators are those students who are physically present but mentally not there. They would be back benchers, make little or no eye contact with the teacher or peers, be sleeping or doing something else other than the classwork [2].

Mustapha, Rahman, and Yunus [13] found that the characteristics of the teacher and the classmates influence the levels of classroom participation. Teachers who were "encouraging, supportive, understanding and approachable" were successful in garnering class participation and responses from their students. On the contrary "negative traits like having poor teaching skills and being unapproachable discourages participation". Signs of disapproval, discouragement or lack of interest on the part of the class fellows also served as a deterrent [13-2]. Furthermore, "rolling their eyes, sighing loudly, frowning, and other nonverbal signals sent from nonparticipating students to participating students relay the message that others disapprove of their behaviour", as explained by Loftin and Hartin [13].

In the context of English as a Foreign Language (EFL), research informs that generally Asian students tend to be passive and reluctant to participate (Lee, [16]; Liu,[ 17). Mack [18] emphasized the importance of the role of teachers and learners in classroom participation and concluded that "oral participation evokes feelings of power and powerlessness". Students who don't participate tend to feel excluded and are ignored by the peers. He stressed on social inclusion, teaching methodology and student voice as key factors for ensuring equitable class participation.

By preparing themselves to participate in the class, students become highly motivated [19], pick up information well [2], appear as more critical thinkers [20], and feel self-reported achievements in character [21]. Their increase in participation leads to decrease in their memorization, and enhances their engagement in greater thinking abilities, including understanding, examination, and creation [22]. There has been reported an improvement in communication power [23], group collaborations [24], and working in a self-governing society [25].

It has been reported that majority of students in early grades as well as in higher grades do not willingly take part in classroom activities. Many factors has been reported that could have promoted to this undesirable behavior, such as being in a new school atmosphere, nervousness, less content knowledge, anxiety about humiliation, or language problem. On the other hand, "appropriate and relevant questioning, teachings applicable to their daily lives, helpful classroom environment, and a positive response participation grade influence the increased classroom participation [14]. The inclination to participate may be affected by both gender and values (Victoria University of Wellington, 2000). Males report more participation as compared to females, which has been verified through research as well [26]. Fritschner [26] highlights "lack of preparedness and not enough time to clearly formulate their thoughts" as the main reason which hinders participation of both genders. Constantinople, Cornelius, and Gray, J. [27] in their study emphasized on the relationship between class size and participation. They assert that the class participation is very low in a large sized class and vice versa.

On the bases of literature review, factors can be classified as internal factors and as external factors. Internal factors may comprise of students motivation, interest, inclination, abilities, previous knowledge and physical and learning disabilities while age, peers, teachers' behavior, parents support, social and economic status of parents, classroom environment, curriculum etc. comes in external factors.

Majority of research already conducted in the area recognized class participation and investigated it by measuring students' achievement scores. Achievement scores may or may not be equaled as "participation" slightly differs with instructors and researchers. Dancer and Kamvounias [23] considered participation as an active involvement process which can be built upon five steps: planning, involvement in discussion, collaborative skills, communication abilities, and presence. Earlier, [24] reported six levels of students' participation perceived by teachers, advancing from simply their presence in the class 
to giving oral presentations.

The present research intended to examine current level of students' classroom participation at secondary level and to compare the secondary school students 'participation by gender in terms of influencing factors. Four null hypotheses relevant to the present research were formulated to investigate.

- Secondary school students have no significant level of classroom participation.

- No gender differences exist in classroom participation of secondary school students.

- No gender differences exist in factors lies behind students' classroom participation.

- Internal and external factors behind classroom participation have no significant correlation.

\section{Method}

The present descriptive study was conducted in quantitative paradigm. Survey technique was used to collect data. All students from $9^{\text {th }}$ and $10^{\text {th }}$ grade enrolled in public high schools of Lahore city comprised the population. For sample selection, a list of public schools in Lahore was obtained from district education office. There were 19 boys' and 21 girls' government high schools in Lahore city, from which a sample size of $10 \%$ was calculated. From these, 2 schools were randomly selected from each cohort. Five hundred 9 th and $10^{\text {th }}$ grade students were purposively selected for data collection from a total of1689 students enrolled in the sample schools. Two hundred and fifty students from each cohort, boys' and girls' were accessed. Based on the literature review, a self-reported questionnaire on a 5-point Likert scale was developed. First half of the questionnaire aimed to find the level of participation of students, and the second half to identify the internal and external factors behind classroom participation. Validity and reliability were established after conducting a Pilot test. The instrument was distributed among 50 students from a public high school. Using Cronbach's Alpha, internal consistency coefficient was computed, and its value was found to be .90 . Further, the experts in the field of testing and measurement verified the face and content validity of the instrument.

Table 2.1. Item distribution among different sub categories

\begin{tabular}{|c|c|c|c|}
\hline $\mathrm{Sr} \#$ & Factors & Sub categories & Statement no 's \\
\hline 1 & Internal & Motivation, Fear, \& self esteem & $1-6,7-10,11-13$ \\
\hline 2 & External & Teachers, Parents, Peers, Curriculum, classroom environment & $14-19,20-22,23-28,29-32,33-36,37-40$, \\
\hline
\end{tabular}

\section{Findings}

Simple descriptive statistics and Independent sample t-test was applied to analyze the data.

Table 3.1. Overall Classroom Participation Level of Secondary School Students

\begin{tabular}{|c|c|c|c|c|c|c|}
\hline Sr \# & Groups & N & Mean & SD & df & t-value \\
\hline & Boys & 145 & 109.81 & 18.99 & 309 & \\
\hline & Girls & 173 & 100.89 & 15.64 & & 3.749 \\
\hline
\end{tabular}

$p \geq .05$

An independent samples $t$ test was conducted to explore the impact of gender on overall classroom participation level of secondary school students. There was a statistically significant difference at the $\mathrm{p}<.05$ level in participation level for boys $(M=109.81, S D=18.99)$ and girls $(M=100.89, S D=15.64) ; \mathrm{t}(309)=3.749, \mathrm{p}=.000$ (two tailed). Hence, the null hypothesis was rejected and it was inferred that boys have higher participation level than girls.

\subsection{Internal Factors}

Table 3.1.1. Influence of Motivation on Classroom Participation of Secondary School Students

\begin{tabular}{|c|c|c|c|c|c|c|}
\hline Sr \# & Groups & N & Mean & SD & df & t-value \\
\hline 1 & Boys & 168 & 120.97 & 20.04 & 334 & \\
\hline 2 & Girls & 171 & 129.59 & 19.12 & & 2.033 \\
\hline
\end{tabular}

$p \geq .05$

The results of 168 boys $(M=120.97, S D=20.04)$ and the 171 girls $(M=129.59, S D=19.12)$ from secondary schools revealed a significant difference on motivation scale $(t[334]=2.033, p<.05)$; girls students were more influenced by their academic motivation as compared to boys. 
Table 3.1.2. Influence of Fear on Classroom Participation of Secondary School Students

\begin{tabular}{|c|c|c|c|c|c|c|}
\hline $\mathrm{Sr} \#$ & Groups & $\mathrm{N}$ & Mean & $\mathrm{SD}$ & $\mathrm{df}$ & t-value \\
\hline 1 & Boys & 169 & 101.10 & 11.58 & 324 & \\
\hline 2 & Girls & 154 & 110.84 & 17.48 & & 1.449 \\
\hline
\end{tabular}

$p \geq .05$

Table 3.1.3. Influence of Self-Esteem on Classroom Participation of Secondary School Students

\begin{tabular}{|c|c|c|c|c|c|c|}
\hline $\mathrm{Sr} \#$ & Groups & $\mathrm{N}$ & Mean & $\mathrm{SD}$ & $\mathrm{df}$ & $\mathrm{t}$-value \\
\hline 1 & Boys & 168 & 111.97 & 19.04 & 349 & \\
\hline 2 & Girls & 191 & 103.11 & 16.38 & & 3.147 \\
\hline
\end{tabular}

$p \geq .05$

The 168 boys $(M=111.97, S D=19.04)$ and the 191 girls $(M=103.11, S D=16.38)$ from secondary schools demonstrated a significant difference in scores, $t(349)=3.147$. It can be concluded that boys' high self-esteem leads to their comparatively high participation.

\subsection{External Factors}

Table 3.2.1. Influence of Teachers on Classroom Participation of Secondary School Students

\begin{tabular}{|c|c|c|c|c|c|c|}
\hline Sr \# & Groups & $\mathrm{N}$ & Mean & SD & df & t-value \\
\hline 1 & Boys & 171 & 115.59 & 16.13 & 349 & \\
\hline 2 & Girls & 179 & 105.84 & 12.48 & & 2.289 \\
\hline
\end{tabular}

$$
p \geq .05
$$

The 171 boys $(M=115.59, S D=16.13)$ and the 179 girls $(M=105.84, S D=12.48)$, demonstrated a significant difference on scale $t(349)=2.284$. Boys were more influenced by teachers 'traits, behavior and skills as compared to girls.

Table 3.2.2. Influence of Parents on Classroom Participation of Secondary School Students

\begin{tabular}{|c|c|c|c|c|c|c|}
\hline $\mathrm{Sr} \#$ & Groups & $\mathrm{N}$ & Mean & $\mathrm{SD}$ & $\mathrm{df}$ & t-value \\
\hline 1 & Boys & 154 & 113.07 & 17.19 & 321 & \\
\hline 2 & & & & & & 4.411 \\
\hline
\end{tabular}

$p \geq .05$

Results indicate a significant difference between score of boys $(\mathrm{M}=113.07, \mathrm{SD}=17.19)$ and girls $(\mathrm{M}=109.50$, $S D=15.25), t(321)=4.411$. It was inferred that boys from secondary schools were more influenced by parents than girls.

Table 3.2.3. Influence of Peers/Friends on classroom participation of Secondary school students

\begin{tabular}{|c|c|c|c|c|c|c|}
\hline Sr \# & Groups & $\mathrm{N}$ & Mean & SD & df & t-value \\
\hline 1 & Boys & 145 & 102.32 & 12.83 & 339 & \\
\hline 2 & Girls & 199 & 98.15 & 10.61 & & 3.763 \\
\hline
\end{tabular}

$p \geq .05$

Data analysis revealed a significant difference between boys $(M=102.32, S D=12.83)$ and girls' score $(M=98.15$, $S D=10.61), t(339)=3.763$. It was concluded that boys from secondary schools were more influenced by their class fellows as compare to girls were.

Table 3.2.4. Influence of Curriculum on Classroom Participation of Secondary School Students

\begin{tabular}{|c|c|c|c|c|c|c|}
\hline Sr \# & Groups & $\mathrm{N}$ & Mean & SD & df & t-value \\
\hline 1 & Boys & 131 & 18.57 & 3.17 & 316 & \\
\hline 2 & & & & & & 3.829 \\
\hline$p \geq .05$
\end{tabular}

A significant difference between scores of boys and girls of secondary schools was reported. It was concluded that 
classroom participation of boys from secondary schools was more influenced by curriculum as compared to girls.

Table 3.2.5. Influence of Classroom Environment on Classroom Participation of Secondary School Students

\begin{tabular}{|c|c|c|c|c|c|c|}
\hline Sr \# & Groups & N & Mean & SD & Df & t-value \\
\hline 1 & Boys & 135 & 111.29 & 4.41 & 320 & \\
\hline 2 & Girls & 188 & 119.68 & 3.90 & & 3.487 \\
\hline
\end{tabular}

$p \geq .05$

Descriptive statistics revealed a significant difference between scores of both gender on classroom environment scale. It was concluded that classroom participation of girls was more influenced by classroom environment as compare to boys of secondary schools.

Table 3.2.6. Influence of Seating Position on Classroom Participation of Secondary School Students

\begin{tabular}{|c|c|c|c|c|c|c|}
\hline Sr \# & Groups & $\mathrm{N}$ & Mean & SD & Df & t-value \\
\hline 1 & Boys & 163 & 105.79 & 16.35 & 322 & \\
\hline 2 & Girls & 171 & 109.54 & 18.05 & & 1.164 \\
\hline
\end{tabular}

$p \geq .05$

Table indicates an insignificant difference in total sores. Seating position is a significant factor which influences both boys and girls of secondary schools at the same rate.

Table 3.2.7. Relationship between Internal and External Factors of Secondary School Students

\begin{tabular}{|c|c|c|c|c|c|c|}
\hline $\mathrm{Sr} \#$ & Secondary & Factor & Min & Max & $\mathrm{n}$ & $\mathrm{r}$ \\
\hline 1 & School & Internal & 49 & 106 & 117 & $537^{* *}$ \\
\hline 2 & Students & External & 45 & 135 & & \\
\hline
\end{tabular}

**Correlation is significant at the 0.01 level (2-tailed).

A significant positive correlation between internal and external factors was found. This correlation indicated that internal factors were correlated to external factors.

\section{Conclusions}

Data analysis reveals that secondary school students participate in classroom at a considerably significant level, and boys participate more than girls. Internal and external factors influence both genders almost in the same way. Motivation is an important factor which influenced girls more than boys. Fear is a significant negative factor which lies behind classroom participation and both genders were influence by it in the same way. On the other hand, self-esteem differently effects classroom participation of boys and girls. Self-esteem enhances classroom participation of boys more as compared to girls. Teachers, parents and peers and curriculum are important external factors which support boys classroom participation more than girls who in the turn more influenced by classroom environment. Seating position had same effect on classroom participation of both genders. Results report that internal factors of classroom participation are positively associated with external factors.

\section{Discussion}

Mustapha, Abd Rahman and Yunus [12] reported strong students' participation in the class. Their results are in line with the findings of the present research. They aimed to identify factors that influence undergraduate students' participation in Malaysian classrooms. in contrast to the present research, they conducted interviews and observations. The results reported that teachers' characteristics and classfellows' behavior had a significant role in increasing student participation. These results are in line with the findings of present research as teachers and peers were found to be significantly influential factors for classroom participation. This finding endorses the results of studies conducted by Fassinger (2000), who also found that teachers' communication skills shapes and promote classroom interaction. Turk [33] found in another context of online course that student achievement, their gender and weekly hours of internet use directly related with their participation level in discussion forums. His conclusion supports the present study, which reports not only significantly different participation level of both gender but the extent of difference of internal and external factors. Chandran [34] opined that seating arrangements in the class could have some influence as well. Berdine [35] considered that seating in circular structures is more appropriate for classroom participation. On the other hand, the present study reveals no significant influence of seating arrangement on the students' classroom participation. This may be due to different cultural contexts.

Yusuf [36] reported quality wise low participation in 
observed class. He further indicated teacher domination, students' low contribution, and students' improper learning behavior in the class. He assumed that quality of classroom participation was influenced by teacher's incompetence in class management; teacher's questioning strategy, and students' self-confidence and their vocabulary mastery.

\subsection{Recommendations}

The present study recommends teachers to formulate and adopt instructional strategies that promote students' participation at secondary level. Students should be made to realize by the teachers, that their behaviors can influence, and disturb other students'. Results of the present study have shown that class fellows or friends are highly influential in encouraging or discouraging classroom participation. Students should know that their behavior can enhance others learning and they themselves can take benefit of it. There is a reciprocal relationship among them which leads to enhancement in achievements of all. Teachers play a vital role in boosting participation by acknowledging all contributions made in class as important. They can involve the students by facilitating them to overcome their fear of speaking, and providing examples related to their' lives. A supportive, non-threatening and open learning environment provided by teachers would make students feel comfortable in expressing their thoughts.

\section{REFERENCES}

[1] Petress, K. (2006). An operational definition of class participation. College Student Journal, 40(4), 821-823.

[2] Weaver, R. R., \& Qi, J. (2005).classroom organization and participation: college students' perception. The Journal of Higher Education, 76(5), 570-601. http://dx.doi.org/10.1353/jhe.2005.0038

[3] Cohen, M. (1991).Making class participation a reality .PS: Political science and Politics, 24(04), 699-703.

[4] Howard, J. R., Henney, A.L. Student participation and instructor gender in the mixed-age college classroom. Journal of Higher Education. 1998; 69: 384-405.

[5] Chickering, A.W., \& Gamson, Z.F. (1987). Seven principles for good practice in undergraduate education. AAHE Bulletin, 39(7): 3-7

[6] Pascarella, E.T. \& Terenzini, P.T. 2005, How College Affects Students: A Third Decade of Research (Vol. 2), Jossey-Bass, San Francisco. Kuh, G. D., \& Umbach, P. D. (2004). College and character: Insights from the National Survey of Student Engagement. New Directions for Institutional Research, 122, 37-54. http://dx.doi.org/10.1002/ir.108

[7] Reda, M. (2009). Between speaking and silence: A study of quiet students. Albany, NY: SUNY Press
[8] .Fassinger, P. A. (2000). How classes influence students' participation in college classrooms. Journal of Classroom Interaction, 35, 38-47

[9] Deering, C., Shaw, S. Dealing with difficult students in the classroom. Nurse Educator. 1997; 22:19-23.

[10] Howard, J. R., Henney, A.L. Student participation and instructor gender in the mixed-age college classroom. Journal of Higher Education. 1998; 69: 384-405.

[11] Loftin, C; Davis, L; \& Hartin, V. (2010).Classroom participation: A student perspective, Teaching and Learning in Nursing, ISSN: 1557-3087, Vol: 5, Issue: 3, Page: 119-124.

[12] Mustapha, M. S., Nik-Abd-Rahman, S. N., \& Yunus, M. M. (2010). Factors influencing classroom participation: a case study of Malaysian undergraduate students. Procedia Social and Behavioral Sciences, 9, 1079-1084. http://dx.doi.org/10.1016/j.sbspro.2010.12.289

[13] Dallimore, E.J., Hertenstein, J.H., Platt, M.B. (2004) Classroom participation and discussion effectiveness: Student-generated strategies. Communication Education; 53: $103-115$.

[14] Bean, J. C. and Peterson, D. (1998), Grading Classroom Participation. New Directions for Teaching and Learning, 1998: 33-40. doi:10.1002/t1.7403

[15] Lee E. (2007). Linguistic and cultural factors in East Asian students' oral participation in university classrooms. International Education, 36, 27-47

[16] Liu, N.-F., Littlewood, W. Why do many students appear reluctant to participate in classroom learning discourse? System. 1997; 25: 371-384.

[17] Mack, L (2012). Does every student have a voice? Critical action research on equitable classroom participation practices, Language Teaching Research, Vol 16, Issue 3, pp. 417 - 434. 10.1177/1362168812436922

[18] Junn, E. (1994). "Pearls of wisdom" Enhancing students class participation with an innovative exercise. Journal of Instructional Psychology, 21, 385-387.

[19] Garside, C (1996).Look who's talking: A comparison of lecture and group discussion teaching strategies in developing critical thinking skills, Communication Education, 45(3), 212-227.

[20] Kuh, G. D., \& Umbach, P. D. (2004). College and character: Insights from the National Survey of Student Engagement. New Directions for Institutional Research, 122, 37-54. http://dx.doi.org/10.1002/ir.108

[21] Smith, D. H. (1996). Developing a more interactive classroom: A continuing odyssey. Teaching Sociology, 24, 6475.

[22] Dancer, D. \& Kamyounias, P. (2005).Student involvement in assessment: a project designed to assess class participation fairly and reliably .Assessment \& Evaluation in higher education, 30(4), 445-454.

[23] Armstrong, M., \& Boud, D. (1983). Assessing participation in discussion: An exploration of the issues. Studies in Higher Education, 8, 3344.

[24] Girgin, K. Z., \& Stevens, D. D. (2005). Bridging in-class 
participation with innovative instruction: Use and implications in a Turkish university classroom. Innovations in Education and Teaching International, 42, 93106.

[25] Fritschner, L.M. (2000).Inside the undergraduate college classroom: Faculty and students differ on the meaning of student participation. Journal of higher education, 342-362.

[26] Constantinople, A., Cornelius, R., \& Gray, J. (1988). The chilly climate: Fact or artifact? Journal of Higher Education, 59(5), 527-550.

[27] Fassinger, P.A. (1995). Understanding classroom interaction: Students' and professors' contributions to students' silence. Journal of higher education, 66(1), 82-

[28] Cohen, M. (1991).Making class participation a reality. PS: Political science and Politics, 24(04), 699-703.

[29] Wade, R.C. (1994).Teacher education students' views on class discussion: Implications for fostering critical reflection. Teaching and Teacher Education, 10(2), 231-243.

[30] Anderson, R. C., Nguyen-Jahiel, K., McNurlen, B., Archodidou, A., Kim, S., Reznitskaya, A., et al. (2001). The snowball phenomenon: Spread of ways of talking and ways of thinking across groups of children. Cognition and Instruction, 19, 1- 46.

[31] Hatano, G. (1993). Time to merge Vygotskian and constructivist conceptions of knowledge acquisition. In E. A. Forman, N. Minick, \& C. A. Stone (Eds.), Contexts for learning: Sociocultural dynamics in children's development (pp. 153-166). New York: Oxford University Press.

[32] Reznitskaya, A., Anderson, R. C., McNurlen, B., Nguyen-Jahiel, K., Archodidou, A., \& Kim, S. (2001). Influence of oral discussion on written argument. Discourse Processes, 32, 155-175.

[33] Fawzia Al-Seyabi. (2002). Factors Affecting Students' Oral Participation in University Level Academic Classes within the Omani Context. Second Annual National National ELT Conference. March, $27-28$, 2002. Sultan Qaboos University, Oman.

http://www.essex.ac.uk/linguistics/pgr/egcl/gspd5/Abstracts /AlSeyabi.shtm.

[34] Turk, E. (2010). An Investigation Of Factors Affecting Student Participation Level In An Online Discussion Forum, The Turkish Online Journal of Educational Technology, 9 (2).

[35] Chandran, R. (2015) Mandatory class participation: Factors that influence, classroom practices and learning outcomes. Asian Journal of the Scholarship of Teaching and Learning, 5(2), 108-122.

[36] Berdine, R. (1986).Why some students fail to participate in class. Marketing News, 20(15), 23-24.

[37] Yusuf, I (2007) Classroom Participation: A Case Of A Junior High School Students In EFL Contextfile.upi.edu/.../Paper_CONAPLIN_Participation_Fa zri\%26Intan.pdf. 